\title{
Evaluation and Ranking of Geothermal Resources for Electrical Generation or Electrical Offset in Idaho, Montana, Oregon and Washington
}

by

R. G. Bloomquist, G. L. Black, D. S. Parker, A. Sifford, S. J. Simpson, and L. V. Street

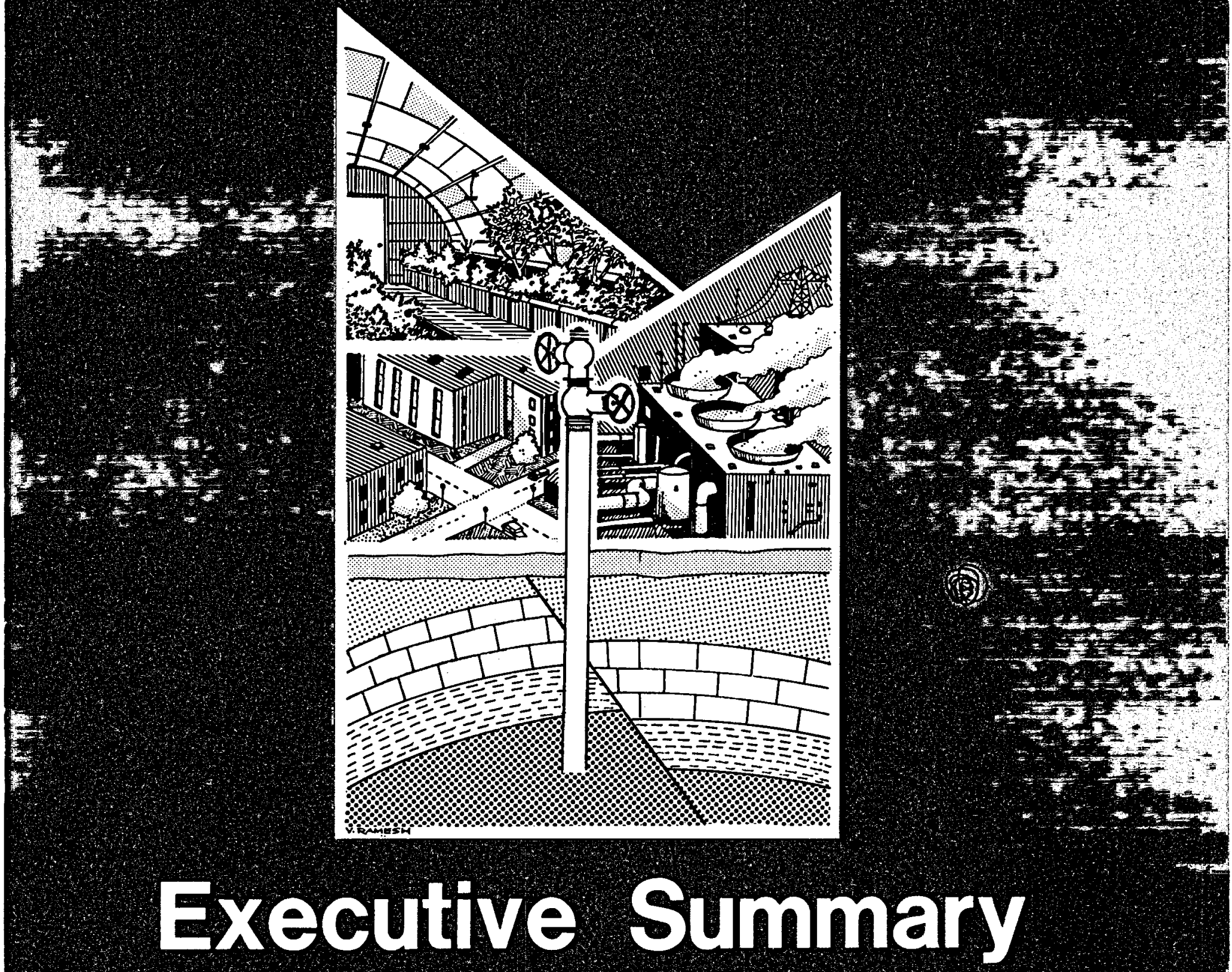




\section{DISCLAIMER}

This report was prepared expressly for use by the Bonneville Power Administration. Neither the Bonneville Power Administration nor the United States Department of Energy, nor any of their employees, nor any of their contractors, subcontractors, or their employees, makes any warranty, expressed or implied, or assumes any legal liability or responsibility for the accuracy, completeness, or usefulness of any information presented. The views and opinions of authors expressed herein do not necessarily state or reflect those of the United States Government or any agency thereof. Reference herein to any specific product, process, or service by trade name, mark, manufacturer or otherwise, does not necessarily constitute or imply its indorsement or recommendation or favoring by the United States Government or any agency thereof. 


\section{DISCLAIMER}

Portions of this document may be illegible in electronic image products. Images are produced from the best available original document. 
Evaluation and Ranking of Geothermal Resources for Electrical Generation or Electrical Offset in Idaho, Montana, Oregon and Washington

Executive Summary

prepared for

Bonneville Power Administration

U.S. Department of Energy

Portland, OR

by

Washington State Energy Office in cooperation with:

Idaho Department of Water Resources

Montana Department of Natural Resources \& Conservation

Oregon Department of Energy

Oregon Department of Geology and Mineral Industries

Principal Investigator

R. GORDON BLOOMQUIST, Ph.D.

June, 1985 

EXECUTIVE SUMMARY

Table of Contents

ACKNOWLEDGEMENTS $\ldots \ldots \ldots \ldots \ldots \ldots \ldots \ldots \ldots$ vii

ABSTRACT $\ldots \ldots \ldots \ldots \ldots \ldots \ldots \ldots \ldots \ldots \ldots, 1$

INTRODUCTION

\section{HIGH TEMPERATURE GEOTHERMAL RESOURCE} EVALUATION AND RANKING BASED ON DEVELOPABILITY AND COST ..............

Introduction ......................... 3

Developability Index ................... 3

The Uncertainty Problem ................ 5

Summary .......................... 5

Estimating Development Costs of

Geothermal Electricity ..............6 6

Cost Estimate Methodology .............. 6

Remaining Assessment Work .........6 6

Permits and Licenses.............. 6

Well Costs ....................... 7

Wellfield \& Power Plant............. 7

Adjustments.................... 8

Transmission Lines................. 8

Application .................... 8

Estimating the Levelized Cost of

Geothermal Electricity ................. 9

First Year Costs and Produced Power ........................ 10

Estimating Nominal and Constant Dollar Cost Streams ............. 10

Calculating Levelized Present

Value of the Cost Stream ........... 11

Application ......................11

Ranking ......................... 11

DIRECT USE GEOTHERMAL RESOURCES

EVALUATION AND RANKING BASED ON

DEVELOPABILITY AND COST

Introduction ........................ 13

Developability Index ................... 13

Cost Estimates .....................16

Ranking ......................... 16

NOTES AND COMMENTS $\ldots \ldots \ldots \ldots \ldots \ldots \ldots \ldots \ldots \ldots$

LEGAL, INSTITUTIONAL, ENVIRONMENTAL

ISSUES AND CONCERNS ................. 19

Introduction .......................... 19

Legal and Institutional $\ldots \ldots \ldots \ldots \ldots \ldots \ldots \ldots \ldots 19$

Environmental ......................... 19

SUMMARY AND RECOMMENDATIONS $\ldots \ldots \ldots \ldots \ldots 21$

REFERENCES $\ldots \ldots \ldots \ldots \ldots \ldots \ldots \ldots \ldots \ldots \ldots \ldots \ldots \ldots$

\section{TABLES}

1. High Temperature Resource Ranking Criteria ..........................

2. Variables for the Correlation Procedure.........................

3. Resource Conditions and Conversion Procedures ........................ 7

4. Geothermal Cost Estimates .............. 9

5. Economic Parameter for Study ............ 10

6. Geothermal Project Data ................ 10

7. Ranking Groups for High Temperature Sites ............................ 12

8. Direct Utilization Ranking Criteria......... 13

9. Variables for the Correlation Procedure......................... 14

10. Ranking Groups for Direct Utilization Sites .................. 16

\section{FGURE}

1 Estimated Reservoir Temperatures .......... 4

2. Age and Type of Volcanism ............... 4

3 Estimated Drilling Depth................. 4

4 Distance to Powerlines ................... 4

5. Special Regulatory/Environmental

Concerns ......................... 4

6. Distance to Legally-Designated Areas ....... 4

7. CENTPLANT Cost Estimate Sheet .......... 11

8. High Temperature Economic/Developability Matrix.......................... 12

9. Known Temperature of Fluids ............. 14

10. Total Flow Rate ...................... 14

11. Estimated Pumping Depth................ 15

12. Annual Heating Load/Density ............. 15

13. Least Cost Heat Energy .................. 15

14. Special Regulatory/Environmental Concerns ......................... 15

15. Direct Utilization Economic/Developability Matrix........................... 16 


\section{ACKNOWLEDGEMENTS}

\section{Acknowledgements}

This assessment of the geothermal potential of Idaho, Oregon, Montana and Washington reflects the work of many individuals and groups and could not have been completed without their full cooperation and support.

The authors would like to express their appreciation and give special recognition to Jeff Birkby and George Priest for their efforts in helping to establish this multi-state effort and to Dave McClain whose work served as the basis for the developability index adopted by the Assessment Team.

Special appreciation is expressed to the Washington Department of Natural Resources and especially to Eric Schuster and Mike Korosec for providing valuable resource data and to Don Hall and Keith Leker who are responsible for preparing the excellent graphics found throughout the report.

Our special thanks to Charlotte Gruessing and Linda Eklund for their work on preparing the manuscript.

Dr. Lee Porter has had overall responsibility for the editing and publishing of the report.

Finally, the authors would like to give special recognition to the members of the Technical Advisory Committee who gave so freely of their time and expertise in the development of the overall ranking methodology used in this study.
Technical Review Committee

Eliot Allen

Carlin Jackson

Eliot Allen \& Assoc., Inc.

U.S. Forest Service

Jeff Birkby

Paul Lienau

Energy Division, Montana

OIT

Department of Natural

Geo Heat Center

Resources \& Conservation

Joe LaFleur

Frank Cochrane

California Energy Co.

Bechtel Group, Inc.

Charles Condy

California Energy Co.

David McClain

Morrison-Knudson

Company, Inc.

Gene Culver

Leroy Mohorich

OIT

Geo Heat Center

Bureau of Land Mgmt.

Gerald Patchen

Bob DeTar

U.S. Forest Service

Bureau of Land Management

Jim Dumble

Idaho Power Company

Jack Feuer

George Priest

Oregon Dept. of Geology

and Mineral Industry

Kevin Rafferty

Bureau of Land Management

OIT

Geo Heat Center

Tom Giese

PNUCC

Jim Turner

Idaho Power Company

Paul Groner

Seattle City Light

Al Waibel

Columbia Geoscience

Jerry Hankin

Bechtel Group, Inc. 
viii 


\section{EXECUTIVE SUMMARY}

\section{ABSTRACT}

In 1983, the Bonneville Power Administration contracted for an evaluation and ranking of all geothermal resource sites in the states of Idaho, Montana, Oregon, and Washington which have a potential for electrical generation and/or electrical offset through direct utilization of the resource.

The objective of this program was to consolidate and evaluate all geologic, environmental, legal, and institutional information in existing records and files, and to apply a uniform methodology to the evaluation and ranking of all known geothermal sites. This data base would enhance the making of credible forecasts of the supply of geothermal energy which could be avallable in the region over a 20 year planning horizon.

The four states, working together under a cooperative agreement, identified a total of 1,265 potential geothermal sites. The 1,265 sites were screened to eliminate those with little or no chance of providing either electrical generation and/or electrical offset. Two hundred and forty-five of the original 1,265 sites were determined to warrant further study.

The Four-State team proceeded to develop a methodology which would rank the sites based upon an estimate of development potential and cost. Development potential was estimated through the use of weighted variables selected to approximate the attributes which a geothermal firm might consider in its selection of a site for exploration and possible development. Resource; engineering; and legal, institutional, and environmental factors were considered. Cost estimates for electrical generation and direct utilization sites were made using the computer programs CENTPLANT, WELLHEAD, and HEATPLAN. Finally, the sites were ranked utilizing a technique which allowed for the integration of development and cost information.

On the basis of the developability index, 78 high temperature sites and 120 direct utilization sites were identified as having "good" or "average" potential for development and should be studied in detail.

On the basis of cost, at least 29 of the high temperature sites appear to be technically capable of supporting a minimum total of at least $1,000 \mathrm{MW}$ of electrical generation which could be competitive with the busbar cost of conventional thermal generating technologies. Sixty direct utilization sites have a minimum total energy potential of $900+M W$ and can be expected to provide substantial amounts of electrical offset at or below present conventional energy prices.

The combined development and economic rankings can be used to assist in determining sites with superior characteristics of both types. Five direct utilization sites and eight high temperature sites were identified with both high development and economic potential. An additional 27 sites were shown to have superior economic characteristics, but development problems.

The procedure seems validated by the fact that two of the highest ranking direct utilization sites are ones that have already been developed - Boise, Idaho and Klamath Falls, Oregon. Most of the higher ranking high temperature sites have received serious examination in the past as likely power production candidates.

\section{INTRODUCTION}

The commercial use of geothermal energy in the Pacific Northwest Region of Idaho, Montana, Oregon, and Washington began with the construction of the Warm Springs Heating District in Boise, Idaho, in the early 1890's. The resource was, however, considered to be little more than a novelty instead of a major energy resource until at least the early 1960's when the first successful American use of geothermal energy to produce electricity occurred at The Geysers in northern California.

Interest in geothermal energy peaked in the early 1970's with the passage of the Geothermal Steam Act of 1970, the Arab oil embargo of 1973-74, the establishment of the federal geothermal leasing program in 1974, and the publishing by the United States Geological Survey of USGS Circular 726--Assessment of Geothermal Resources of the United States--in 1975.

Interest in geothermal energy remained high through the late 1970's and early 1980's due to ever increasing oil prices and a second major oil shortage in 1979.

By 1981, however, major changes began to occur at the tional level. Oil prices stabilized and a diminished emphasis was placed on the development of renewable energy resources. Two new players entered the energy future of the BPA four-state region in 1981. The passage of the Pacific Northwest Electrical Power Planning and Conservation Act (P.L. 96-50) in December 1980, created the Pacific Northwest Power Planning Council, and also gave the Bonneville Power Administration (BPA) new authority and responsibility for providing and regulating a majority of the region's electrical power supplies. Although the national emphasis on energy development was waning, a forecasted local electrical energy deficit and the provisions of the Pacific Northwest Electrical Power Planning and Conservation Act helped maintain a regional emphasis upon geothermal exploration and development.

By late 1981, however, the local electrical energy picture changed, and the forecasted deficit was replaced by a forecasted long-term surplus. The need for accelerated exploration vanished as did the dream of many energy development companies that rising regional electrical 
prices would create a profitable market for geothermal energy. With the announced surplus, energy planners throughout the region returned to their drawing boards and focused attention on how to best determine resource potential, development potential, and costs; and what activities should be undertaken to ensure that costeffective geothermal resources could be brought on-line to meet future demand.

At this time, the Bonneville Power Administration turned to the Washington State Energy Office (WSEO) and requested that WSEO coordinate a detailed regional geothermal assessment program to bring together expertise existing in the respective state energy and resource offices of the northwest. The objective of this program was to consolidate and evaluate all geologic, environmental, and legal and institutional information in existing records and files, and to apply a uniform methodology to the evaluation and ranking of all known geothermal sites. This data base would allow the making of creditable forecasts of the supply of geothermal energy which could be available in the region over a 20 year planning horizon. The report which this summarizes is the result of this request by $B P A$.

To accomplish the given tasks, the Four-State Team was established and team members initially identified a total of 1,265 potential resource sites from existing literature. Site selection was based upon the presence of thermal and mineral springs or wells and/or areas of recent volcanic activity and high heat flow. The 1,265 sites were then screened to eliminate those which had little or no chance of development because of inadequacies of resource temperature, legal prohibitions against development, or inadequate heat demands within economical transmission distances of direct use resource sites. Of the original 1,265 sites, 245 sites were selected for detailed analysis.

The first task was to develop a methodology to rank the sites according to energy potential, degree of developability, and cost of energy.

Energy potential was determined using the methodology established by the United States Geological Survey for assessment of the geothermal potential in the United States. The methodology is explained in detail in USGS Circulars 726, 790, and 892.

Resource developability was determined by a method based on a weighted variable evaluation of resource favorability. This technique is an expansion of one developed by McClain in 1980, and it has been significantly modified to allow for full consideration of the large uncertainties that surround geothermal resource assessment. At this point in the project, a Technical Review Committee (see acknowledgements) made up of representatives from regulatory agencies, utilities, energy companies, and engineering firms was established to oversee the development of the developability index and the overall ranking system which was to include resource parameters and energy cost as well as legal, institutional; and environmental data.

Levelized energy costs for electrical generation are based upon estimates developed by Bechtel National Inc. under contract to the Assessment Team. Direct use costs are calculated using the computer program HEATPLAN, developed by Eliot Allen and Associates for the Washington State Energy Office under separate contract.

Finally, sites were ranked using an integration of values determined through cost and developability analyses.

The full report from which this summary was taken is published in two volumes and is available through the Bonneville Power Administration, Portland, Oregon. Volume One is an account of the methodology established for determining resource and energy potential, site developability, the costs of energy, site rankings, conclusions and program recommendations, and a complete reference list. Volume Two includes the various computer codes used in the analyses, supporting documentation, and the outputs of the analyses. 
HIGH TEMPERATURE GEOTHERMAL RESOURCE EVALUATION AND RANKING BASED ON DEVELOPABILITY AND COST

Introduction

The Four-State Team originally identified 1,265 potential geothermal sites. Of this number, 100 sites passed temperature and land use screens and were given further consideration as potential electrical generation sites. Sites over $90^{\circ} \mathrm{C}$ (1940F) were characterized, evaluated, and ranked according to energy potential, degree of developability, and cost of energy. Energy potential was determined according to established practices of the United States Geological Survey

\section{Developability Index}

The methodology begins with a listing of the major factors believed to be related to the developability of a geothermal resource for electric power generation. Numerical estimates are assigned to each of the variables to indicate their relative importance in the assessment. The estimates are based on the delphi approach using the "expert opinion" of resource regulators, geologists, energy planners, and engineers. The variables used and their relative weights are presented in Table 1. The values

TABLE 1

High Temperature Resource Ranking Criteria Characteristic Numerical Weight

\section{Resource}

Estimated Reservoir Temperature

Potential for High Permeability

14

Age and Type of Volcanism

Estimated Drilling Depth

Prospect Areal Extent

Drilling Difficulty

Heat Flow

Total

$\begin{array}{r}12 \\ 8 \\ 4 \\ 4 \\ 4 \\ \hline 60\end{array}$

II. Engineering

Distance to Powerlines

Terrain of Powerline Corridor

Resource Site Accessibility

Terrain of Development Site

Distance to Heating Load

Annual Heat Load/Density

Total

$\begin{array}{r}10 \\ 6 \\ 4 \\ 4 \\ 3 \\ 3 \\ \hline 30\end{array}$

III. Institutional/Environmental

Special Regulatory/Environmental

Concerns

Land/Resource Management

Percent Leased for Exploration

Distance to Legally Designated Areas

Air/Water Concerns

Total

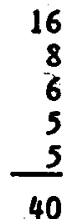

GRAND TOTAL assigned to the individual variables have been selected to approximate the various attributes a geothermal firm might consider in its assessment of a geothermal site.

For each of the variables, a dependent variable is selected. Selecting a dependent variable allows a researcher to correlate the variables and determine a relative score for each resource on the basis of the above characteristics. A perfect resource score is 130 . The dependent variables and their associated units are listed in Table 2.

TABLE 2

Variables for the Correlation Procedure

\begin{tabular}{|c|c|c|}
\hline IMDEPENDENI YARIABLES & UNUS & DEPEYYDEET YARLABLES \\
\hline TEKPERATURE & oc & $\begin{array}{l}\text { ESTIMATED RESERVOIR } \\
\text { TEMPERATURE }\end{array}$ \\
\hline $\begin{array}{l}\text { FAUR TIME/EXISTEMCE OF FLUIDS } \\
\text { TYPE/COKPOSITION OF ROCKS }\end{array}$ & NA & Potemtial for Permeabilitity \\
\hline AND AGE & NA & AgE AMD TYPE of VOLCANISK \\
\hline $\begin{array}{l}\text { DEPIH IN MEIERS } \\
\text { ESTIMAIED ROCK TYPE } \\
\text { SURFICIAL AREA - SOUARE }\end{array}$ & $\stackrel{M}{M A}$ & $\begin{array}{l}\text { DriLling DePth } \\
\text { DriLling Difficulit }\end{array}$ \\
\hline $\begin{array}{l}\text { Riloneters } \\
\text { MiLlivatrs Per Souare Heter } \\
\text { SLope of Terraim }\end{array}$ & $\begin{array}{l}K x^{2} \\
M K / K M^{2} \\
M A\end{array}$ & $\begin{array}{l}\text { PROSPECT AREAL EXTEMT } \\
\text { REGIONAL HEAT FLOY } \\
\text { TERRAIK OF POUERLIME } \\
\text { CORRIDOR }\end{array}$ \\
\hline KILOMETERS & $\mathbf{K M}$ & Disiance to PouerL jues \\
\hline ACCESS ROAD TYPE & NA & Resource Site Accessibility \\
\hline NUMBER OF TERRAIN COMCERHS & NA & TERRAIK OF DEVELOPHENT SIJE \\
\hline DEGREE OF URBAMIZATIOA & MA & $\begin{array}{l}\text { Meat Load Deasity } \\
\text { Heation }\end{array}$ \\
\hline $\begin{array}{l}\text { Private/FEDERAL/MIXED } \\
\text { Number OF SPECIAL. COMCERHS }\end{array}$ & MA & $\begin{array}{l}\text { LAMD/RESOURCE MAMAGEKEMT } \\
\text { SPECIAL EMVIROMKEMTAL } \\
\text { CONCERHS }\end{array}$ \\
\hline Decimal Fraction Leased & $\mathbf{z}$ & $\begin{array}{l}\text { PERCEMT LEASEd For } \\
\text { EXPLORATION }\end{array}$ \\
\hline KILOKETERS & KM & $\begin{array}{l}\text { DistakCe to Legally- } \\
\text { Designated AREas }\end{array}$ \\
\hline $\begin{array}{l}\text { Ho. of Pollutants ABove } \\
\text { EPA REG. }\end{array}$ & MA & Air/Hater Comcerms \\
\hline
\end{tabular}

Based on geologic and engineering information, relationships between the dependent variables and the ranking criteria were established. These relationships were expressed in graphic form then adjusted by linear and nonlinear curve fitting procedures to determine the fractional score of the independent ranking variables. The nonlinear curves were fit with a seven-degree polynomial regression. This is expressed as:

$$
Y=B 0+B 1 \times X+B 2 \times X^{2} \ldots+B 7 \times X^{7}
$$

Where: $Y$ = the fractional score for the

$$
\mathrm{BO}=\text { the regression constant }
$$

$\mathrm{B1}$... B7 = regression coefficients determined from correlation 
In all cases $R$-squared was in excess of .99. The score from the correlation procedure is always between 0 and 1 , so that the final score is constrained to between 0 and the maximum numerical weight. Also, a score of 0 for reservoir temperature, reservoir permeability, and drilling depth results in the total assessment being multiplied by the factor (0)--thus, a 0 score overall. Figures 1 through 6 are examples of the graphic relationships between ranking criteria and the fractional scores of some of the more critical characteristics.

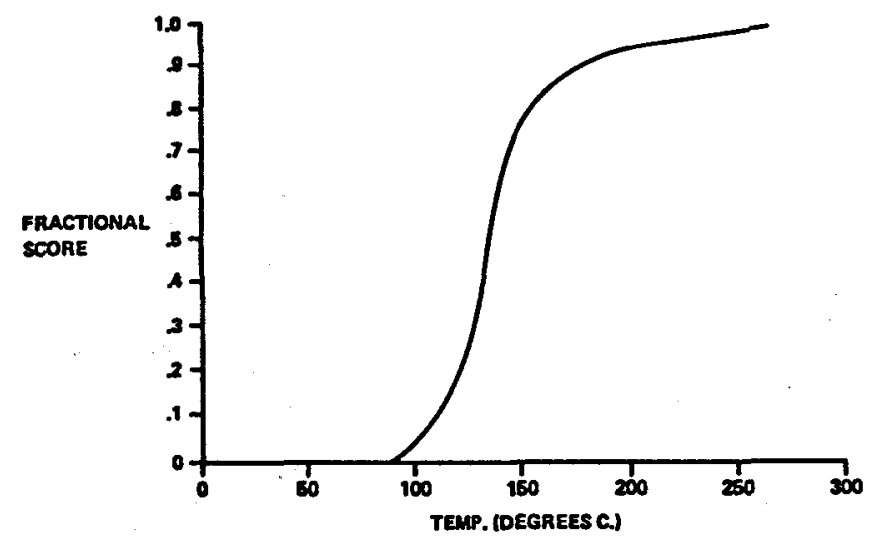

FIGURE 1 - Estimated Reservoir Temperature

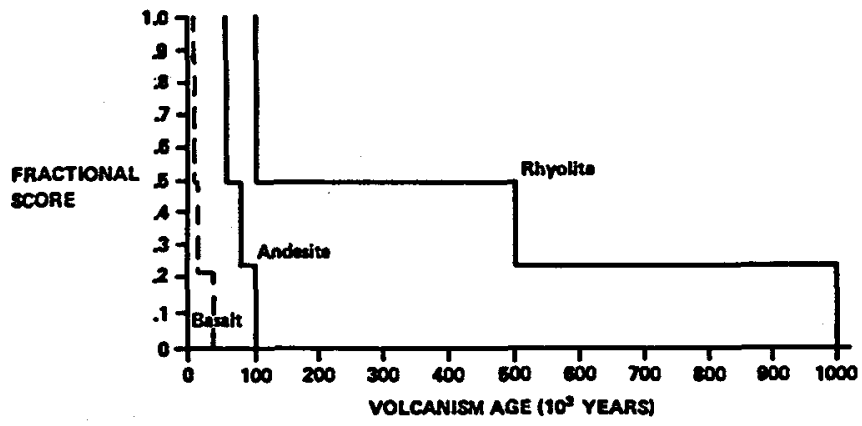

FIGURE 2 - Age and Type of Volcanism

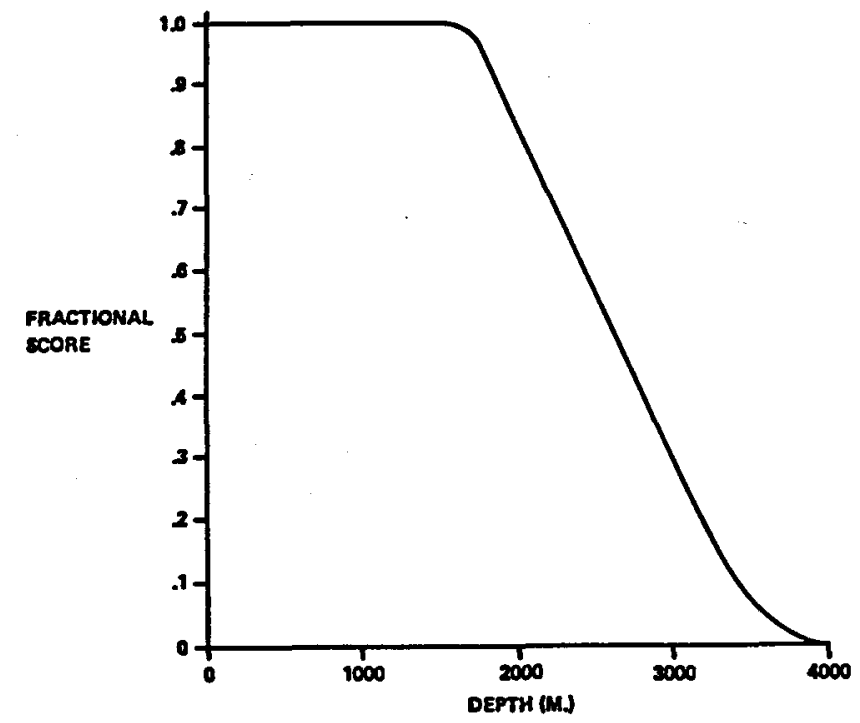

FIGURE 3 - Estimated Drilling Depth

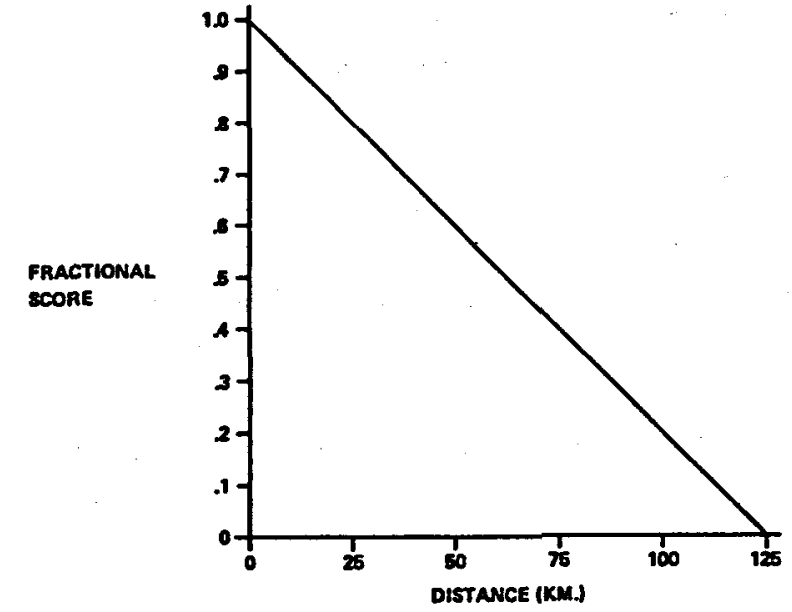

FIGURE 4 - Distance to Powerlines

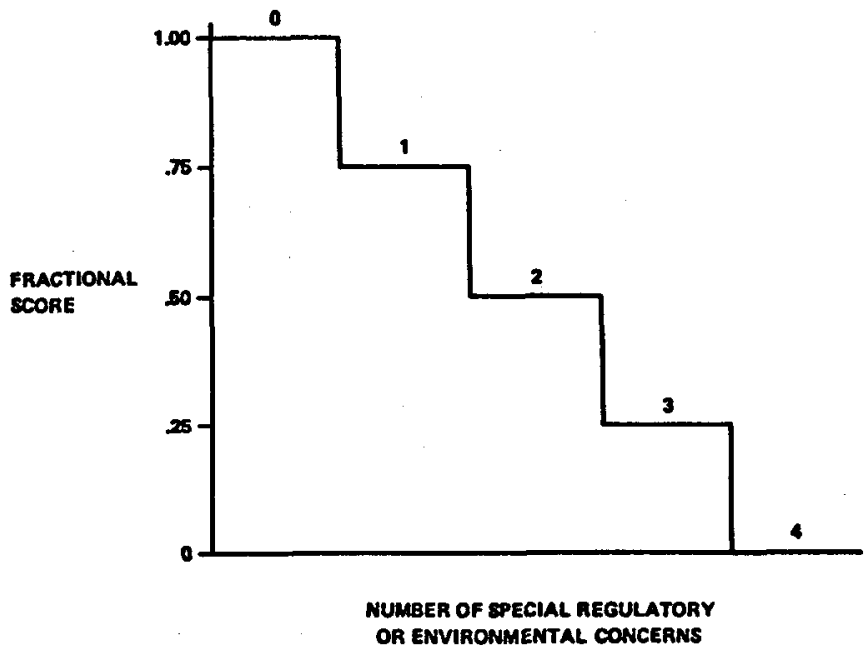

FIGURE 5 - Special Regulatory/Environmental Concerns

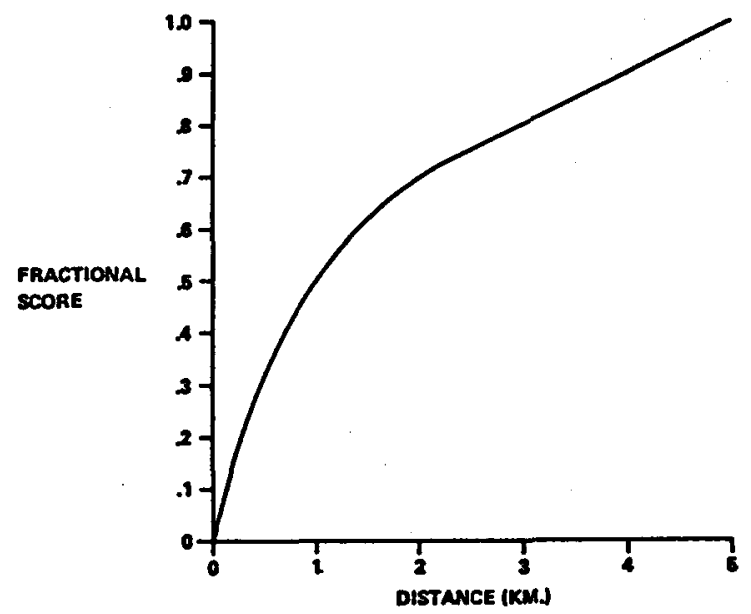

FIGURE 6 - Distance to Legally-Designated Areas

After estimating values from the correlation variables for each resource, the dependent value is used to estimate the fractional score for each ranking criteria characteristic. The final scores are subsequently summed to determine a final score for each site. The sites with the highest scores are deemed to be those with the greatest development potential. 


\section{The Uncertainty Problem}

Unfortunately, the score that results from the above procedure often is based on exceedingly uncertain estimates. This is largely due to the "blind" nature of geothermal resources. It is, therefore, desirable to give serious consideration to the effect which such uncertainties have upon the overall score which is assigned to each resource characteristic. Often the exact location or the very existence of a high-temperature resource may be uncertain even when extensive surface geology and geophysical studies have been completed. The estimated flow rates that might be available are seldom known and can lead to project failure. Reservoir volume, recharge rate, and lifetime are almost always unknown.

Drilling can help to define the resource, but costs can be high and the payoff of geothermal wells generally is less than that associated with hydrocarbon exploration. Whereas, an oil drilling program that produces from one in ten wells might be profitable, geothermal drilling programs seldom can afford such a low success rate. If 'P' is the probability of success and ' $n$ ' equals the number of trials, then the cumulative probability of failure is simply described as:

$$
(1-P)^{n}
$$

To illustrate, a geothermal well drilled to a depth of one kilometer might cost $\$ 350,000$. Thus, a drilling program with a $\$ 1$ million allowance for three holes and a 60 percent confidence in finding suitable fluids would still have to risk a 6.4 percent chance of total fallure, or so called "Gambler's Ruin." The magnitude of this uncertainty in geothermal drilling is well known. Edmiston (1982) found only an 11.3 percent success rate in 53 geothermal wildcat wells drilling in promising areas from 1974 through 1981.

Furthermore, this risk is from only one uncertainty in the project, whereas uncertainty typically exists in several aspects. An appropriate evaluation of the uncertainty would account for the cumulative risks and their effect on project feasibility.

Geological evaluations involving uncertainty typically use Monte Carlo simulation with triangular probability distribution. This method is accurate but computationally tedious, often requiring thousands of iterations for reasonable accuracy. In the method selected by the team, a simple cumulative error model is used to evaluate uncertainty. The certainty of estimates is based on drilling and geologic information. In the absence of hard data, estimates are made by inference from drilling results in similar geologic formations.

Given a fractional certainty level 'P,' for an estimate, the fractional uncertainty is 1-P. Therefore, the most likely uncertainty in the point score (FS) is:

$$
(1-\text { P) FS }
$$

Cumulative maximum uncertainty is thus:

$$
\sum_{i=1}^{n}\left(1-P_{i}\right) F S_{i}
$$

It is assumed, however, that the uncertainty errors in the estimates are serially independent. As a result, the most probable uncertainty is given by the root mean of the sum of the squared uncertainties. This can be expressed by:

$$
u_{c} \text { prob }=\sqrt{\sum_{i=1}^{n} \frac{\partial F S-\partial x i^{2}}{\partial x i}}
$$

Where:

$$
\begin{aligned}
\mathbf{U}_{\mathbf{C}} \text { prob }= & \text { most likely uncertainty in assessment } \\
& \text { score } \\
\partial \mathrm{FS} & =\text { change in fractional score } \\
\partial \mathbf{x}_{\mathbf{i}} & =\text { change in parameter "} \mathbf{x}_{\mathbf{i}} \text { " examined } \\
\mathbf{n} & =\text { number of uncertainties examined }
\end{aligned}
$$

The specification does not require that maximum and minimum estimates be made. A certainty level is provided for each estimate for the seven resource variables, and the uncertainty is assumed to be distributed normally about the most likely figure. The number used for ranking purposes is the most likely minimum score that is conveniently both the mean and mode of the distribution. This assumption reflects the economic reality that firms investing in a risky venture often are more concerned with the possibility of the worst case than with maximum project payoffs.

\section{Summary}

The method allows comparative ranking of high temperature geothermal resource sites. The technique includes representation of the cumulative uncertainties in the estimates and is broadly applicable to sites in 
different regions and circumstances. The method, however, tends to bias against sites for which little resource information is known and where default values must be depended upon.

\section{Estimating Development Costs of Geothermal Electricity}

The next step was to develop typical site configurations based on conversion technology commensurate with known or estimated resource temperature. This allowed engineering estimates of capital and operating expenses to be developed for each site. Finally, the engineering cost estimates were fed into an economic model resulting in levelized energy cost estimates.

The objective of the characterization work was to develop generic capital and operation and maintenance (O\&M) costs for geothermal wells, wellfield surface facilities, and power plants for the range of plant capacity from less than $1 \mathrm{MW}$ to $100 \mathrm{MW}$ net. Cost data was derived from a variety of sources familiar with actual costs of existing wells, surface facilities, and plants. Engineering work by Bechtel National, Inc. and the Oregon Institute of Technology furnished cost information used for modeling the various geothermal resource prospects. In this way, realistic estimates for generic costs of facilities are used in the economic ranking phase of the overall study. All costs are in 1984 dollars.

Engineering cost information derived under this task was formatted in a personal computer spreadsheet program, LOTUS 123 (TM). Formulas providing equipment costs and operating costs were set up on the spreadsheet to accommodate site-specific inputs, e.g., resource temperature and depth, distance to transmission lines.

\section{Cost Estimate Methodology}

The complete costs of geothermal power development include capital and O\&M costs for geothermal wells, wellfield surface facilities, and power plants, including transformer and switchyard. Costs also include exploration work prior to development. Well cost estimates are conservative. Work by numerous companies, government agencies, and academia provided wellfield and plant cost information. Transmission line cost figures were derived from BPA.

Historically, two parties (a developer and a utility) have been involved in resource supply and power generation. However, both utilities and developers agree that the ability to construct power plants is no longer strictly a utility function. (Based on recent experiences in California, utilities may evolve more into electricity distributors than suppliers.) Because of this, the Assessment Team decided to determine total facility capital costs, including wells. This assumption reflects the vantage of both the developer (be it independent or a utility) and the ratepayer. Total costs are important to both parties. Because of the need for total capital cost estimates, resource supply, and power generation costs were included together. Assuming one entity constructs both fuel supply (wells and wellfield equipment) and the power plant, fuel costs would be zero.

In the situation of a supplier/utility venture, total capital costs would be reduced approximately two-thirds, and well costs would be recovered by the supplier (with a profit) through operating fuel costs. The cost component format used in this project does allow for such estimating to be undertaken.

\section{Remaining Assessment Work}

Given that prudent developers try to verify as much as possible the existence of a resource prior to actual production well drilling, this assessment work must be included in total development costs. Exploration work includes passive techniques such as mapping, sampling existing well, geochemical analyses, and varying levels and types of geophysical surveys. Also included is temperature gradient drilling. Conservative costs were estimated for each exploration phase and task. A matrix indicating completed assessment work at various sites was compiled. The remaining assessment work which would be necessary was determined and costs for that work summed up.

\section{Permits and Licenses}

Recognizing that all power plants will require some regulatory approval, costs of obtaining necessary permits were factored into the sum. It is only conjecture to determine complete siting permit costs at this stage of development in the Pacific Northwest, but site application fees are known.

For example, the Oregon Energy Facility Siting Council requires a $\$ 15,000$ fee when submitting an application for plants over $25 \mathrm{MW}$ in size. Using this amount as a starting point, additional costs would include staff time to hold and attend local, state, and federal hearings; 
miscellaneous permit fees; and administrative/legal challenges. It was therefore determined that an appropriate amount could easily be $\$ 50,000$. These costs are small relative to total plant costs.

\section{Well Costs}

Perhaps the most tenuous cost estimating is deep well cost as very few deep geothermal exploration holes have been drilled in the Cascades. Northwest Natural Gas, with U.S. DOE support, drilled a $1,830 \mathrm{~m}(6,000 \mathrm{ft}$.) well at Old Maid Flat on Mt. Hood in 1980. That hole cost approximately $\$ 1,000,000$ (Geyer, 1984).

Sunedco Inc. drilled a well at the Breitenbush KGRA in 1981 to an estimated 9,000 foot depth. While no published data is available on that hole, the authors sought the advice of the drilling consultant involved in the work.

In the northern Cascades at Meager Creek, British Columbia, three wells averaging 3,000 meters (10,000 ft.) were drilled in 1981 and 1982. Allowing for circumstances peculiar to the project and area, the drilling cost to B.C. Hydro averaged $\$ 4,000,000$ each (Larkin, 1984).

Additional information was obtained from Occidental Geothermal Inc., operator of the only production-size well drilled at the Medicine Lake KGRA in northern California. That well was drilled in 1984 and the site mirrors geologically the environment of Newberry volcano.

Arbitrary but conservative, counseled assumptions used in deriving large, central plant well cost's are as follows:

- Average well depth of 2000 meters $(6,500$ feet);

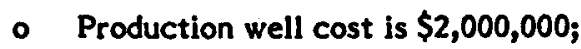

- Injection well cost is the same;

- Production well to injection well ratio is $3: 2$;

- Dry holes are 1 per $10 \mathrm{MW}$ of capacity;

- Power per well is $3 \mathrm{MW}$ in the Cascades, $4 \mathrm{MW}$ in the Basin and Range province.

It is believed that the conservativeness of well cost estimates is commensurate with the level of production well drilling experience in the Pacific Northwest. Well costs associated with drilling low temperature $\left(82-150^{\circ} \mathrm{C}\right)$ (180-3000F) geothermal reservoirs for use with organic Rankine cycle well head generators are based on a simple adjustable dollars per foot formula. Such wells will be constructed in a manner similar to large volume irrigation wells.

\section{Wellfield \& Power Plant}

Data used for developing generic wellfield and plant cost relationships for resources $177^{\circ} \mathrm{C}\left(350^{\circ} \mathrm{F}\right)$ and higher include published estimates for a number of plants that have been constructed and cost estimates from contractor conceptual, preliminary, and dețail designs.

\section{TABLE 3}

\section{Resource Conditions and Conversion Processes}

\begin{tabular}{lcccc} 
& \multicolumn{4}{c}{ Conversion Process } \\
\cline { 2 - 4 } Resource & $\begin{array}{c}\text { Direct } \\
\text { Steam }\end{array}$ & $\begin{array}{c}\text { Single } \\
\text { Flash }\end{array}$ & $\begin{array}{c}\text { Double } \\
\text { Flash }\end{array} \quad$ RST & Binary \\
\hline $\begin{array}{c}\text { Dry steam } \\
180^{\circ} \mathrm{C} \\
\left(355^{\circ} \mathrm{F}\right)\end{array}$ & $\mathrm{X}$ & &
\end{tabular}

\begin{tabular}{|c|c|c|c|c|}
\hline $\begin{array}{l}\text { Hot water } \\
277^{\circ} \mathrm{C} \\
\left(530^{\circ} \mathrm{F}\right)\end{array}$ & $x$ & $x$ & $\mathbf{x}$ & \\
\hline $\begin{array}{l}\text { Hot water } \\
216^{\circ} \mathrm{C} \\
\text { (4200F) }\end{array}$ & $x$ & $x$ & $\mathbf{x}$ & \\
\hline $\begin{array}{l}\text { Hot water } \\
177^{\circ} \mathrm{C} \\
\text { (3500F) }\end{array}$ & & $x$ & $\mathbf{x}$ & $\mathbf{X}$ \\
\hline $\begin{array}{l}\text { Hot water } \\
90-1500^{\circ} \mathrm{C} \\
(194-300 \% \mathrm{~F})\end{array}$ & & & & $x$ \\
\hline
\end{tabular}

For direct steam power plants, a reasonably large amount of data are available due to the extensive development at The Geysers that currently includes 20 generating units ranging from 11 to $135 \mathrm{MW}$ (net). However, the cost data available for plants using hot water resources is not nearly as extensive, since construction in the United States has only recently begun on plants that use these resources. Currently, there are five operating power plants of $7 \mathrm{MW}$ or more capacity in the United States using hot water resources. Three other plants ranging in size from 9 to $47 \mathrm{MW}$ (net) are under construction but are not yet operating.

Plants of the same capacity but using hot water resources with different temperatures and different energy conversion processes would be expected to have somewhat different costs. Therefore, cost relationships were developed for the resource conditions and energy conversion processes as indicated in Table 3. This 
classification makes maximum use of available cost data, and accounts for the cost effects of resources in the range of temperatures that have been exploited to date with plants having $10 \mathrm{MW}$ capacity and greater.

Besides resource temperatures and type of energy conversion process, a number of other technical characteristics may affect the cost of geothermal power plants. For example, if the hydrogen sulfide $\left(\mathrm{H}_{2} \mathrm{~S}\right)$ content of the geothermal fluids is low, there may be no need for an $\mathrm{H}_{2} \mathrm{~S}$ abatement system; on the other hand, all the power plants at The Geysers are required to have equipment for abating $\mathrm{H}_{2} \mathrm{~S}$ to meet California air quality requirements. Because of this, all cost estimates assure that $\mathrm{H}_{2} \mathrm{~S}$ abatement equipment will be required for all steam and flash steam facilities.

\section{Adjustments}

In addition to the characteristics discussed above, two additional factors may influence capital costs: site preparation based on terrain and local labor supply. To account for these two factors, cost relationships are first developed for relatively flat, open terrain sites in areas with adequate local construction labor. Adjustments to these initial cost relationships which take into account mountainous terrain and areas with inadequate local construction labor are then developed. An average of about 2 percent of total plant cost could be expected to represent a generic increase in site preparation cost compared to construction on flat land.

To adjust labor costs for loss of productivity, an average of about 12 percent of labor cost could be expected to represent a generic increase in labor costs in areas similar to The Geysers.

Some remote areas where geothermal power projects may be located are beyond a feasible commuting distance from an adequate pool of construction labor. In situations like this, a construction camp would be established and operated to provide living quarters and meals for the workers.

\section{Transmission Lines}

Transmission line cost data was obtained from the 1984 edition of "Per Mile Cost Data for Preliminary Transmission Line Estimates" (Wright, 1985). The structure chosen as typical is a $115 \mathrm{kv}$, single circuit,
Narcissus conductor wood pole. Costs are complete, including environmental work, surveys, design, materials, construction, land, roads, and overhead. Total cost equals $\$ 107,130$ per $\mathrm{km}(\$ 191,000 / \mathrm{mi})$.

\section{Application}

The intent of applying those methodologies is to estimate current installed capital costs and first year operating costs. Capital and O\&M costs for each high temperature site are derived from applying the previously described methodology. As noted earlier, resource temperature determines which conversion process to use. These engineering costs can then be used in any desired economic forecasting model. Cost estimates were made for plants 10 to $100 \mathrm{MW}$ (net) using the Bechtel methodology. The OIT methodology was applied to plants under $2 \mathrm{MW}$ (net).

Of the original 100 sites, estimates for 19 sites with most likely temperatures above $177^{\circ} \mathrm{C}\left(350^{\circ} \mathrm{F}\right)$ were made using the Bechtel methodology. Cost estimates derived from the Bechtel methodology provide two things: a relative economic ranking of each site and reasonably accurate cost estimates of a $50 \mathrm{MW}$ power plant at each site.

Table 4 provides estimated costs for the 19 applicable sites. The costs calculated include the following:

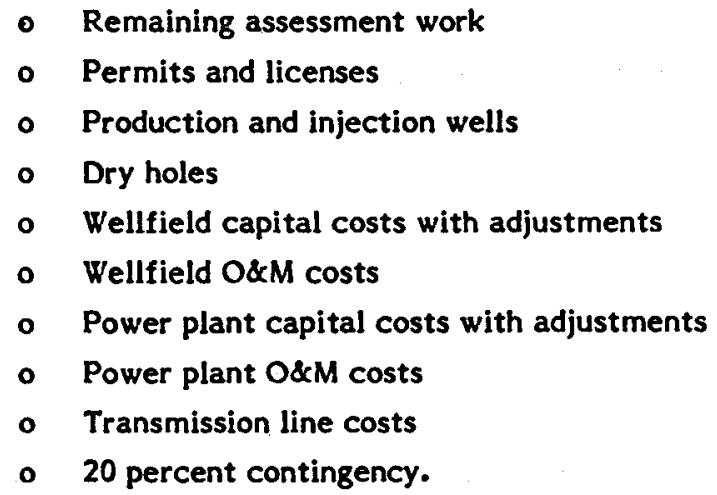

For the remaining 81 sites, the OIT methodology was applied to all except 10 sites where insufficient input data were available. Cost estimates derived from this methodology provide two things: a relative ranking of each site and reasonably accurate cost estimates of .2 - 2 MW wellhead binary power plants at each site. These estimates are liberal in that remaining assessment work, dry holes, and transmission line costs are not included. It is not expected that all exploration steps will be 
completed at each wellhead binary site. Rather, it is assumed that all remaining assessment work will be completed at the highest temperature sites, while moderate temperature sites will proceed with the drilling of the production well constituting a majority of the assessment work.

\section{TABLE 4}

Ceothermal Cost Estimates

\begin{tabular}{|c|c|c|c|}
\hline Site & $\begin{array}{l}\text { Conversion } \\
\text { Process } 1\end{array}$ & $\begin{array}{c}\text { Estimated } \\
\text { Cap. Cost } \\
(\$ / \text { Net kW)2 }\end{array}$ & $\begin{array}{l}\text { Estimated } \\
\text { O\&M Cost } \\
(\$ / \mathrm{kW} / \mathrm{yr})^{3}\end{array}$ \\
\hline Newberry Volcano & SF & 2,957 & 50 \\
\hline Wart Peak Caldera & SF & 3,116 & 63 \\
\hline Glass Buttes & SF & 3,137 & 64 \\
\hline Cappy-Burn Butte & $\mathbf{S F}$ & 3,297 & 63 \\
\hline Mickey HS & SF & 3,305 & 66 \\
\hline Bearwallow Butte & $\mathbf{S F}$ & 3,436 & 62 \\
\hline Melvin/3-Creek Buttes & SF & 3,447 & 62 \\
\hline Vale HS & $\mathbf{B}$ & 3,594 & 82 \\
\hline Klamath Falls area & DF & 3,612 & 89 \\
\hline Olene Gap HS & $\mathbf{D F}$ & 3,615 & 89 \\
\hline Klamath Hills area & DF & 3,636 & 89 \\
\hline Neal HS & DF & 3,652 & 87 \\
\hline Crump HS & DF & 3,660 & 90 \\
\hline Borax Lake HS & DF & 3,762 & 92 \\
\hline Alvord HS & $\mathbf{D F}$ & 3,829 & 92 \\
\hline Trout Creek area & DF & 3,849 & 94 \\
\hline Crater Lake area & DF & 4,030 & 91 \\
\hline Gen. High Cascades & DF & 4,094 & 91 \\
\hline Mt. McLoughlin & DF & 4,147 & 92 \\
\hline TOTAL 39 & & & \\
\hline
\end{tabular}

$1 \mathrm{SF}=$ single flash, $\mathrm{DF}=$ double flash, $\mathrm{B}=$ binary.

2 Costs are complete for a $50 \mathrm{MW}$ net field and plant. Power plant costs alone are approximately one third those shown.

3 Costs include operating labor, maintenance, and overhead.

\section{Estimating The Levelized Cost of Geothermal Electriclty}

The determination of the cost of produced or conserved power from a resource is made more difficult because inflation distorts cost decisions. Inflation often makes it appear as if a resource acquired at a later time is more expensive than one acquired in 1981. In actuality, the decision to bulld now or later may have no effect on the budget. Also, it is difficult to compare the cost of different projects because the expenses may occur at different times. These costs include construction, operation and maintenance, interest, and non-recurring capital and fuel costs. A geothermal project has a very large capital cost associated with the drilling of wells and the building of the generating plant, but the "fuel" is very inexpensive thereafter. On the other hand, a gas combustion turbine may be relatively inexpensive to build, but fuel costs will be quite high over the long run.

The levelized cost method estimates project costs over the resource life through the use of "constant 1984" dollars. Many "cost streams" are uneven because they include different applicable inflation rates, and they must be converted into an equivalent annual cost payments so that the present value of the payments is equal to the original, uneven costs. The nominal cost stream is converted into constant 1984 dollars which are then discounted back to a present value at the resource's startup date. The discount rate one selects is quite important to this process. The recommended BPA value of 3 percent is used throughout the analysis. After being discounted, the present value is amortized back over the project life by the discount rate. The resulting annual cost is then divided by the project energy output to find the levelized cost per kilowatt hour. In this fashion all resources may be evaluated on a consistent basis and ranked accordingly.

The generalized form of the levelized cost equation is:

$$
L C e=\frac{C R F * \sum_{N=1}^{P L} \frac{C n}{(1+D)^{N}}}{E_{0}}
$$

Where:

$$
\begin{aligned}
& \text { LCe = the levelized first year cost (mills/kilowatt } \\
& \text { CRF = Capital Recovery Factor (annuity of } \\
& \text { PL = the project life (years) } \\
& \text { D = real discount rate (nominal/inflation rate) } \\
& C_{n}=\text { sum of costs in year " } n \text { " (capital, }
\end{aligned}
$$

To determine the levelized cost, parameters must be specified for use with the procedure. This takes two 
forms: economic data and project specific data. For the purpose of a consistent evaluation process, all economic parameters (Table 5) and some of the project specifications (Table 6) have been kept constant through the entire evaluation procedure:

\section{TABLE 5}

Economic Parameters for Study

$\begin{array}{ll}\text { Inflation Rate (IR) } & 6 \text { percent } \\ \text { Real Escalation Rate (RE) } & 1.3 \text { percent } \\ \text { Real Discount Rate (D) } & 3 \text { percent } \\ \text { Finance Rate (I) } & 13 \text { percent } \\ \text { Construction Finance Rate (FI) } & 13 \text { percent } \\ \text { Cost Price Level (CP) } & 1984 \\ \text { Year on Line (YOL) } & 1990 \\ \text { Physical Life (PL) } & 30 \text { years } \\ \text { Plant Size (MW) } & 50 \mathrm{MW} \\ \text { Capacity Factor (CF) } & 80 \text { percent } \\ \text { Capital Cost Per kWh (CC) } & \text { Varies } \\ \text { Variable Cost (V) } & \text { Varies } \\ \text { Fixed Costs (F) } & \text { Varies } \\ \text { Cash Flow During Construction (CAn) } & \end{array}$

TABLE 6

Geothermal Project Data

\begin{tabular}{cc} 
Year & Percent of Direct Cost \\
\cline { 2 - 2 } & 20 percent \\
2 & 30 percent \\
3 & 50 percent
\end{tabular}

\section{First Year Costs and Produced Power}

In the following calculations, the cost components are estimated as well as the power produced from the facility. The costs consist of the total installed cost, and the variable, fixed, and operation and maintenance cost components. The power produced is a function of the plant size and average availability:

The annual electrical energy produced from the geothermal plant is:

$$
E=M W \bullet C F \bullet 1000 \mathrm{~kW} / \mathrm{MW} \times 8760 \mathrm{hrs} / \mathrm{yr}
$$

The total installed cost of the plant is:

$$
\mathrm{TCC}=\mathrm{CC} * \mathrm{MW} * 1000 \mathrm{~kW} / \mathrm{MW}
$$

The value $\mathrm{CC}$ is determined from the cost relationships from the Bechtel study and estimated cost for wells for the plant. The annual variable cost for plant operation is:
The annual fixed cost component is:

$$
F C=F * M W * 1000 \mathrm{~kW} / \mathrm{MW}
$$

The annual operation and maintenance costs are:

$$
O M=V A+F C
$$

\section{Estimating Nominal and Constant Dollar Cost Streams}

It then becomes necessary to portray the operation and maintenance costs stream in nominal terms. This is done for each year beginning with 1984. Plant operation is assumed to occur in year seven (1990).

$$
\text { VEn }=O M *((1+I) *(1+R E)) N
$$

Where:

$$
\text { VEn = nominal O\&M costs in year "N" }
$$

The capital cost stream is computed for the construction years:

$$
T_{E}=\operatorname{TCC} * C_{A n} *((1+1) *(1+R E)) N
$$

The total direct cost (TDC) is simply the sum of TEn. Interest during construction is:

$$
\mathrm{IDC}=(\mathrm{TE}) *((1+\mathrm{CIR})(\mathrm{CT}-\mathrm{N}+.5)-1)
$$

The annual mortgage payment is:

$$
M O=(T D C+I D C) * \mathrm{CRF}(P L)
$$

The annual total nominal cost stream is:

$$
\operatorname{CSTn}=\text { MOn }+ \text { VEn }
$$

It is then necessary to convert the total nominal cost stream into constant 1984 dollars:

$$
\mathrm{CNn}_{n}=\operatorname{CST} *(1 /(1+1))^{N}
$$

The total constant dollars is then the sum of the constant dollar cost stream (CNn).

$$
V A=V * E
$$




\section{Calculating Levelized Present Value of the Cost Stream}

The present value of the constant 1984 dollars cost stream is:

$$
P V=\sum_{N=1}^{P L}\left(C D n /(1+D)^{N}\right)
$$

The levelized cost of the present value of the cost stream is the final result of the computations. The levelized cost of power is then obtained by dividing by the annual power produced (E).

$$
L C=\frac{C R F \bullet P V}{E}
$$

"LC" is the levelized cost of power produced and may be compared against another geothermal resource or competing non-renewable resource to determine their relative economic attractiveness.

\section{Application}

Obviously, from the foregoing procedure, the initial cost of the geothermal plant will have a major effect on the levelized cost estimated. From the results of the study subcontracted with Bechtel National Inc. it can be clearly seen that the cost of geothermal plants vary widely based upon the available fluid temperatures, the degree of contaminants in the geothermal fluids, and other site specific characteristics.

For our base case scenario, we assumed a $50 \mathrm{MW}$ plant using $5000 \mathrm{~F}$ feedwater with hydrogen sulfide abatement required. At this level of production, we assumed 17 production wells and 11 injection wells for Cascades sites and 13 production and 8 injection for other sites. Wells were estimated to cost $\$ \mathbf{2}$ million each, assuming a 2,000 meter $(6,500$ feet) drilling depth and $3 \mathrm{MW}$ per well for Cascades sites, and $4 \mathrm{MW}$ per well for others. In addition, we assumed that half of all production wells would be replaced over the project life and 25 percent of the injection wells would be replaced. This also seems very conservative given current geothermal power production experience. These costs were included in the calculations as irregularly occurring operation and maintenance costs.

Figure 7 shows an example of the CENTPLANT cost estimation format. Based on Bechtel advice, all O\&M costs are assumed to be fixed. The total capital cost per $\mathbf{K W}$ is estimated to be $\$ 1,397.77$ in the example.

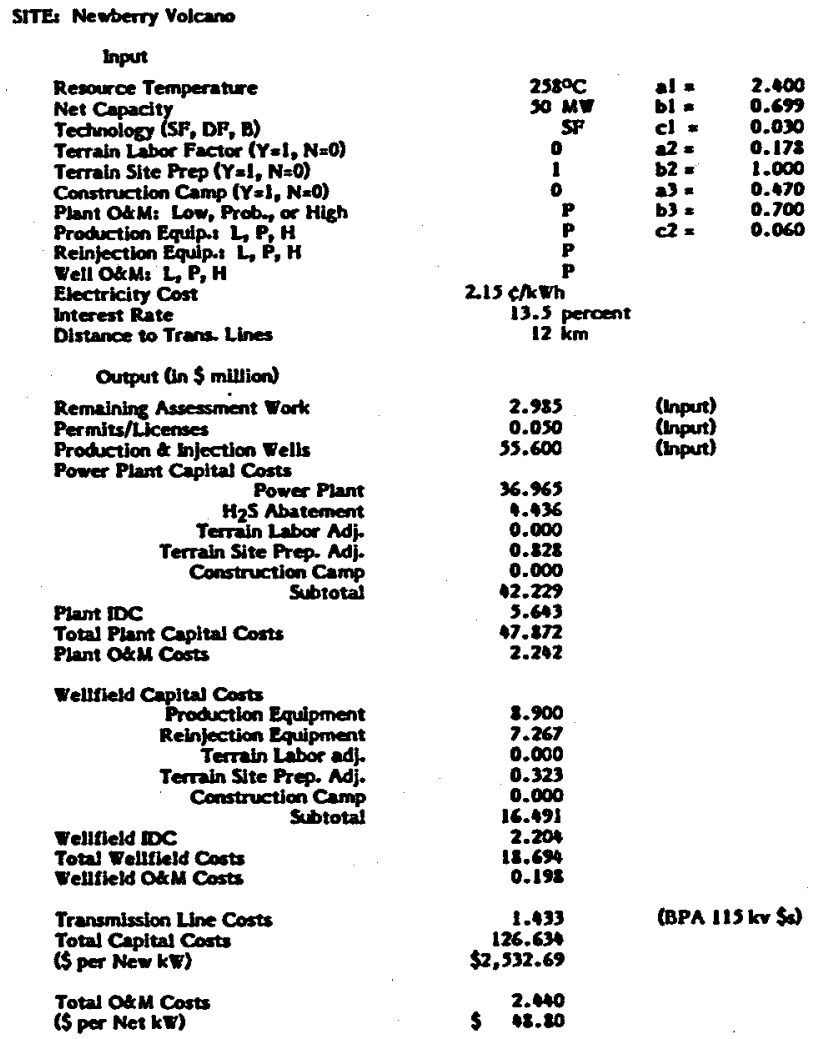

FIGURE 7 - CENTPLANT Cost Entimate Sheet

A microcomputer spreadsheet program was used to create a calculation sequence that performs the above procedure. It uses all the previously described algorithms, and is fast and flexible to use. All input variables are easily entered for parametric study. This program was used to determine the levelized cost estimates used for ranking the geothermal resource sites.

\section{Ranking}

The final geothermal ranking procedure for high temperature sites is based upon the integration of the results of the developability and economic analyses.

The developability ranking is rendered in terms of the normalized minimum score received by the resources sites; that is a score between 0 and 1 indicating the relative favorability for the development of a site. A high score indicates a very developable site. A low score indicates a less developable one. Sites are indicated by their developability score to establish a ranking hierarchy. Following the specific site ranking, the scores are subjected to statistical analysis. Sites are then classified into three general groups with a more robust interpretation. All sites are then assigned into a normal distribution curve. Based on the standard deviation of the distribution, all sites are categorized into one of three groups. These are: sites with good development 
potential, those with average potential, and the others with poor potential.

Based on the mean value and the standard deviation, the sites were classified into these groups. Sites within one standard deviation of the mean were considered to be average sites. Those with a better score than one standard deviation from the mean were considered sites with good development potential; those with scores less than one standard deviation from the mean were considered to have poor development potential. Table 7 shows the ranking groups assigned for the high temperature resource sites.

\section{TABLE 7}

\section{Ranking Groups for High Temperature Sites}

\section{GROUP}

Good SCORE RANGE

Average

$.703-.617$

Poor

$.616-.469$

$.468-.369$

No.

The second part of the ranking procedure adds the economic evaluation of the sites to the development potential assessment shown above. This allows a three by three matrix to approximate geothermal development feasibility in the Pacific Northwest area (Figure 8). The most attractive resources will be those with both high development potential and low cost of produced electrical energy. This two way method is advantageous since it can account for conventionally estimated engineering and economic factors as well as less tangible institutional and market influences. For high temperature resources, the economic parameter used for relative ranking was the estimated levelized cost of produced electricity from each site. The costs varied from 50.22 mills for the most economically attractive site (Newberry Caldera in Oregon), to $272.93 \mathrm{mills} / \mathrm{kWh}$ for the least economically attractive.

In summary, if we define $80 \mathrm{mills} / \mathrm{kWh}$ as a likely boundary for desirable geothermal electricity, this assessment has identified 29 sites with a total minimum potential ca 1,000 MW that warrant further study in regional power planning.

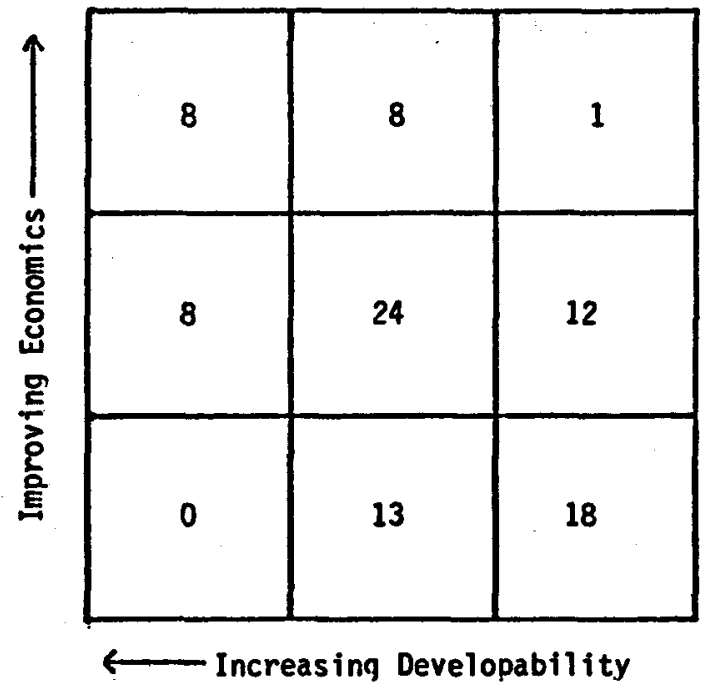

Most Developable/Most Economic

1. Newberry Volcano, OR

2. Crane Creek, ID

3. Klanath Falis, $O R$

4. Glass Buttes, OR

5. Big Creek, ID

6. Raft River, ID

7. Olene Gap, OR

8. Klamath Hills, OR

FIGURE 8 - High Temperature Economic/Developability Matrix 
DIRECT USE GEOTHERMAL RESOURCES EVALUATION AND RANKING BASED ON DEVELOPABILITY AND cost

\section{Introduction}

One hundred and forty-five of the originally identified 1,265 geothermal resource sites were selected by the Four-State Team for detailed characterization, evaluation, and ranking as direct utilization sites. The sites were ranked according to energy potential, degree of developability, and cost of energy. Energy potential has been determined according to established practices of the United States Geological Survey.

For purposes of this portion of the study, direct utilization sites are defined as areas of potential electrical load offset such as towns, cities, or in some cases, resorts, together with the associated geothermal resource(s).

\section{Developability Index}

To evaluate the direct use potential of the geothermal resources of the four state region, it was necessary to develop a technique by which all resources could be evaluated on a common basis and to allow for resource sites to be ranked competitively. In many cases, sufficient information for a detailed engineering and economic analysis was not available. The approach, therefore, was to create a ranking methodology based upon an estimate of developability.

An analytic method was developed based on a weighted variable evaluation of development favorability. The technique is similar to one developed by McClain (1980), but has been modified to tolerate the large uncertainties that surround geothermal resource assessment.

The analysis is generic in nature and permits the relative ranking of resource sites by a developability index. It divides the geothermal development characteristics into three broad areas of concern: resource, engineering, and environmental/institutional factors.

The index begins with a listing of factors that are related to the developability of a resource site for district heating. Numerical estimates are given to each variable to indicate their relative importance. The estimates are

based on a Delphi approach using "expert opinion" of geologists, engineers, city planners, and regulatory agencies. The variables selected and the relative weight assigned to each are presented in Table 8 . The values assigned to the individual variables have been selected to approximate the importance a geothermal firm might place upon them in its selection of a site for development.

TABLE 8

\section{Direct Utilization Ranking Criteria}

\section{Characteristic}

I. Resource

Known Temperature of Fluids

Prospect Areal Extent

Total Flow Rate

Local Gradient

Drilling Depth

Estimated Pumping Depth

Preferred Geothermometer Temperature

Drilling Difficulty

Total

II. Engineering

Annual Heat Load/Density

Distance to Heating Load

Heating Degree Days

Least Cost Heat Energy

Resource Site Accessibility

Terrain of Pipeline Corridor

Trenchability of Pipeline Corridor

Total

III. Institutional/Environmental

Special Environmental Regulatory.

Concerns

Land/Resource Management

Air/Water Concerns

Distance to Legally Designated Areas

Owner Attitude Toward Development

Total

GRAND TOTAL
Numerical

Weight

$\begin{array}{r}11 \\ 8 \\ 7 \\ 6 \\ 7 \\ 5 \\ 4 \\ 2 \\ \hline 50\end{array}$


TABLE 9

Variazles for the Correlation Procedure

\begin{tabular}{|c|c|c|}
\hline INDEPEMDEWT YARIABLES & UMus & DEPEMDENT YARIARLES \\
\hline $\begin{array}{l}\text { TEMPERATURE } \\
\text { SURFICIAL AREA } \\
\text { LITERS PER SECOAD } \\
\text { DEGREES C/KR } \\
\text { DEPIH } \\
\text { DEPIH } \\
\text { TEMPERATURE }\end{array}$ & $\begin{array}{l}\text { oC } \\
\mathrm{KK} 2 \\
\mathrm{LPS} \\
\text { oC/Kn } \\
\mathrm{kn} \\
\text { oc }\end{array}$ & $\begin{array}{l}\text { KNONM TENPS, OF FLUIDS } \\
\text { PROSPECT ARERL EXTEMT } \\
\text { TOTML FLOW RATE } \\
\text { LOCAL GRADIENT } \\
\text { DRILLIMG DEPTH } \\
\text { ESTIMATED PUHPING DEPTH } \\
\text { PREFERRED GEOTHERKOKETER } \\
\text { TERPERATURE }\end{array}$ \\
\hline $\begin{array}{l}\text { ESTIMATED ROCK TYPE } \\
\text { DEGREE OF URBAMIZATIOH } \\
\text { KILOHETERS } \\
\text { HEATING DEGREE DAYS (65\%) } \\
\text { S/106BTU } \\
\text { ACCESS ROAD TYPE } \\
\text { NUMBER OF COHCERHS } \\
\text { SURF ACE ROCK TYPE }\end{array}$ & $\begin{array}{l}\text { NA } \\
\text { NA } \\
\text { KM } \\
\text { of } \\
\text { S/MBTU } \\
\text { NA } \\
\text { KA } \\
\text { NA }\end{array}$ & $\begin{array}{l}\text { DRILLING DIFFICULTY } \\
\text { AMKUAL HEAT LOAD/DEKSITY } \\
\text { DISTANCE TO HEATING LOAD } \\
\text { HEATING DEGREE DAYS } \\
\text { LEAST COSI HEAT EMERGY } \\
\text { RESOURCE SIIE ACCESSIBILITY } \\
\text { TERRAIN OF PIPEL IME CORRIDOR } \\
\text { TREMCHABILIIYY OF PIPELINE } \\
\text { CORRIDOR }\end{array}$ \\
\hline Number of SPECIAL CONCERMS & MA & $\begin{array}{l}\text { SPECIAL EMVIRONMENTAL } \\
\text { REGULATORY CONCERNS }\end{array}$ \\
\hline $\begin{array}{l}\text { PRIVATE, STATE/FEDERAL } \\
\text { OR MIXED }\end{array}$ & MA & LAND/RESOURCE MAMAGEMEMT \\
\hline No. POLLUTANTS ABOVE & MA & $\begin{array}{l}\text { AIR/WATER CONCERMS } \\
\text { EPA REGULATIONS }\end{array}$ \\
\hline Distance & kn & $\begin{array}{l}\text { DISTAMCE TO LEGALLY } \\
\text { PROTECTED AREAS }\end{array}$ \\
\hline POSITIVE OR KEGATIVE & NA & $\begin{array}{l}\text { OUKER AITITUDE TOYARD } \\
\text { DEYEL OPHENT }\end{array}$ \\
\hline
\end{tabular}

Based on geologic, engineering, environmental, and institutional information the relationship between the dependent variable and the ranking criterion were established. These relationships were expressed in graphic form fit by linear and nonlinear curve fitting procedures. The curves are used to determine the fractional score of the independent ranking variables. This determines the points scored for any one resource characteristic from the total available. Linear relationships were fit with a simple least square regression line. The numerous non-linear relationships were fit with a seven degree polynomial regression. This is expressed as:

$$
Y=B O+B 1 * X+B 2 * X^{2} \ldots+B 7 * X^{7}
$$

Where

$$
\begin{aligned}
Y= & \text { the fractional score for the characteristic } \\
& (0-1.0) \\
B= & \text { the regression constant } \\
B 1 . . . B 7= & \text { regression coefficients determined from } \\
& \text { correlation }
\end{aligned}
$$

In all cases, R-squared was in excess of .99. The score from the correlation procedure is always between zero and one, so that the final score is similarly constrained.
After estimates have been made for values of the dependent variables for each resource, they are then correlated to these curves to estimate the fractional score for each ranking characteristic. The factional score is multiplied by the total points available to determine the points scored for any one resource characteristic. The scores for resources, engineering, and institutional/environmental categories are summed separately allowing sites to be ranked against one another on the basis of any one of the major categories. The final score for a site is a sum of the fractional scores of all characteristics. Resource sites with the highest total scores are ranked as those with the greatest development potential.

Figures 9 through 14 are examples of the graphic relationship between ranking criteria and the fractional scores of some of the more critical characteristics.

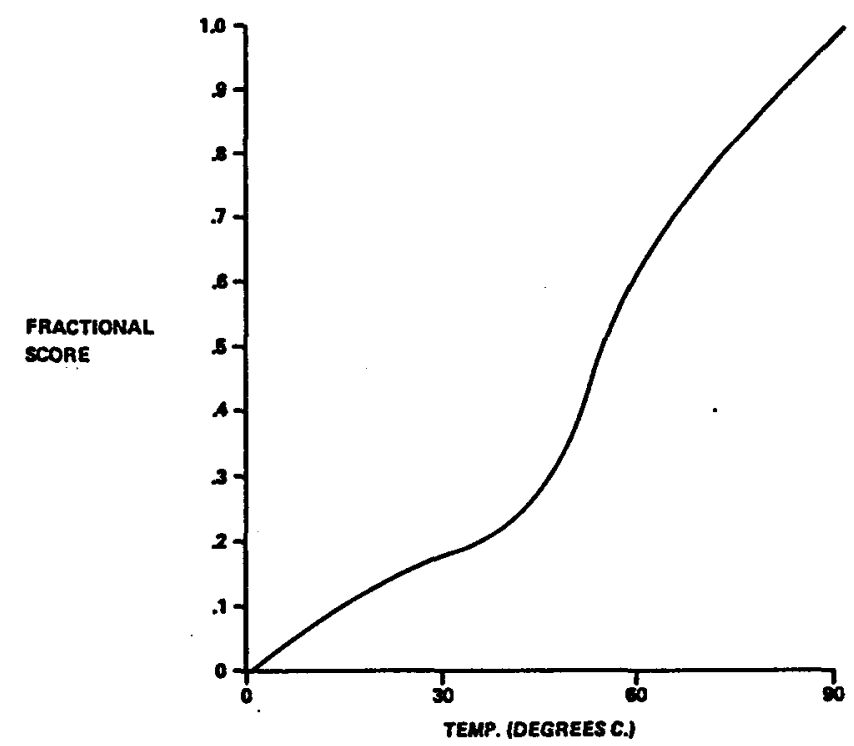

FIGURE 9 - Known Temperature of Fluids

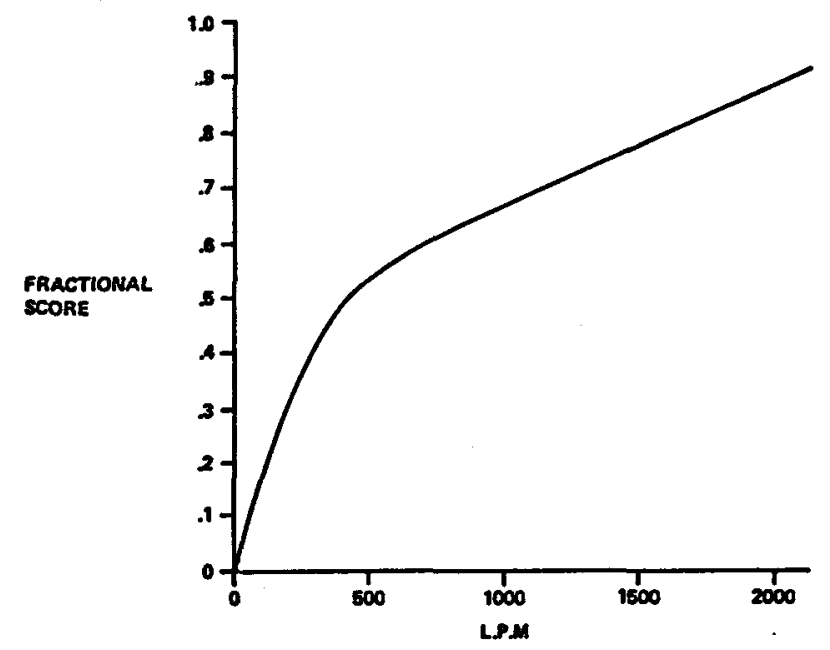

FIGURE 10 - Total Flow Rate 


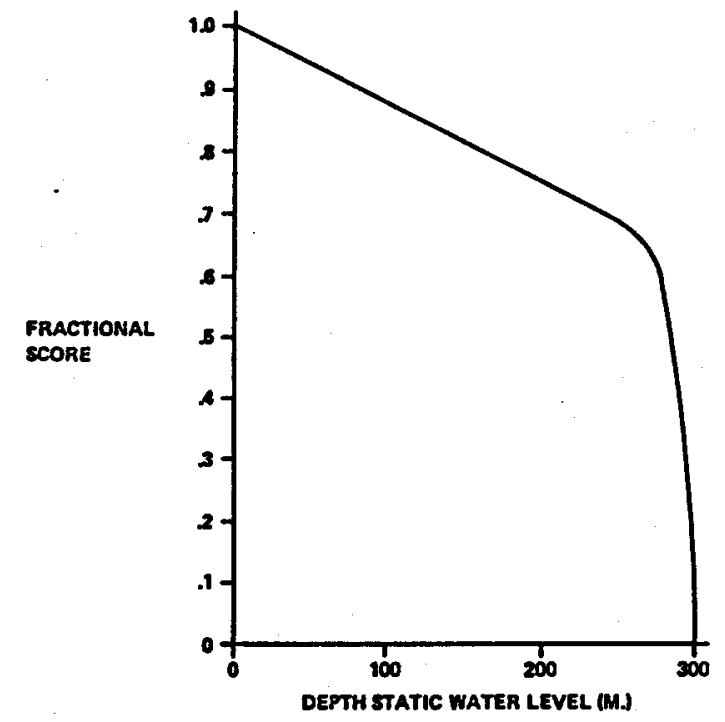

FIGURE 11 - Estimated Pumping Depth

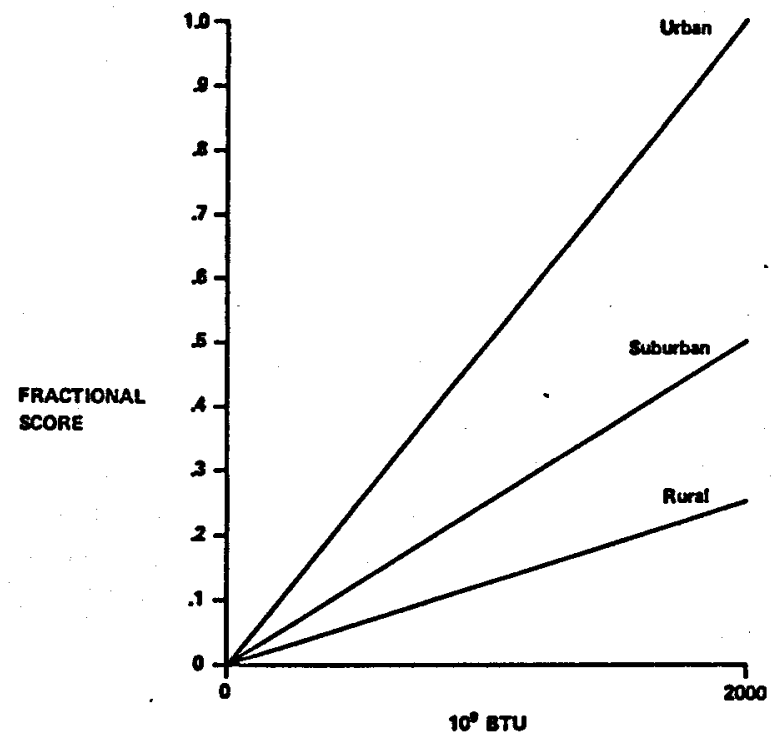

FIGURE 12 - Annual Heating Load/Density

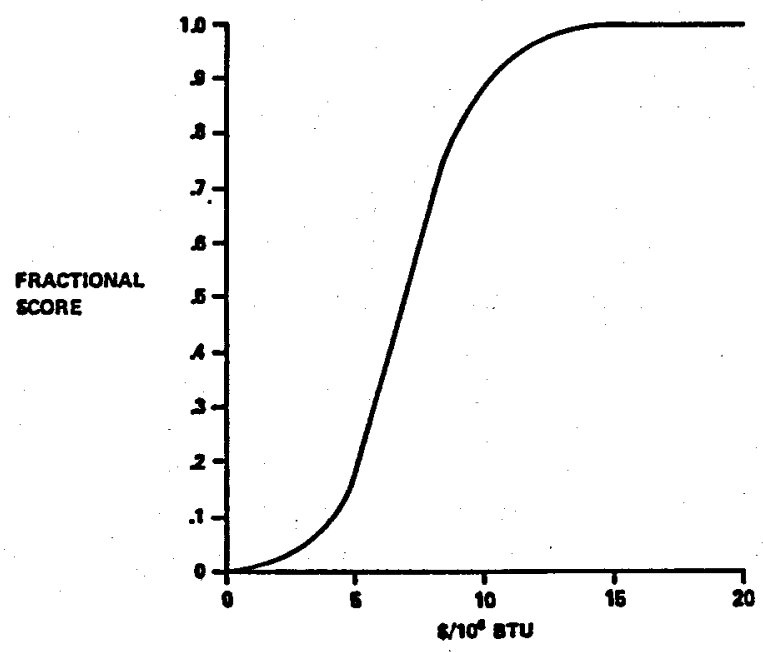

FIGURE 13 - Least Cost Heat Energy

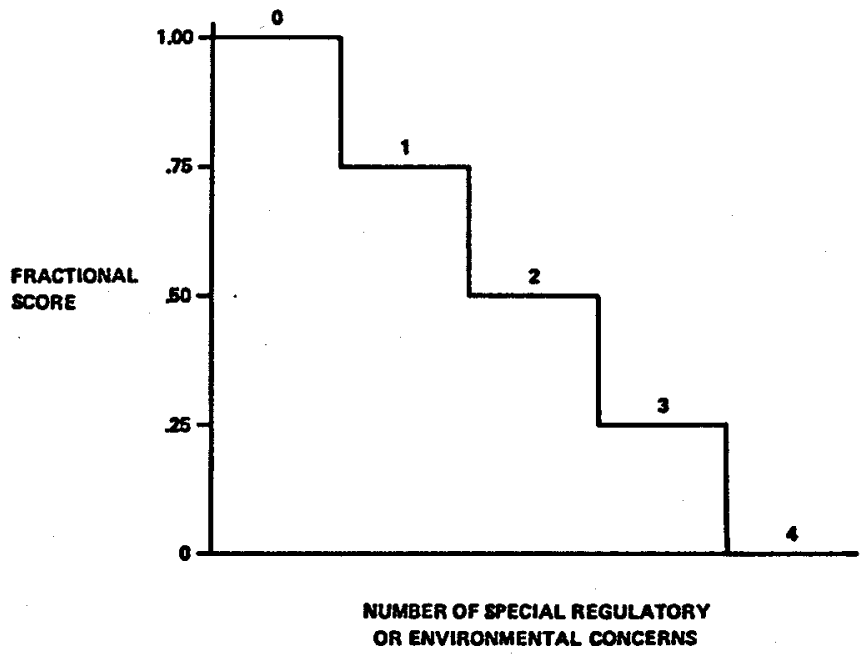

FIGURE 14 - Special Regulatory/Environmental Concerns

The score that results from this procedure is, however, often based on very uncertain estimates due to the blind nature of geothermal resource, and the absence of prior resource evaluation. Because of this, it is necessary to give serious consideration to the effects which such uncertainties have upon the overall score which is assigned to each resource characteristic. Geological evaluations involving uncertainty often use a Monte Carlo simulation with triangular probability distributions. This method is accurate, but is computationally tedious, of ten requiring thousands of iterations for reasonable accuracy. The method chosen for this study is a simple cumulative error model. The root mean sum of the squared errors is used with the implicit assumption that the residual errors of each function are serially independent. It is expressed by the following equation:

$$
U_{c \text { prob }}=\sqrt{\sum_{i=1}^{n} \frac{\partial F S-\partial x i^{2}}{d x i}}
$$

Where

$$
\begin{aligned}
U_{c} \text { prob } & =\text { most likely uncertainty in assessment } \\
\text { score } & \\
\partial F S & =\text { change in the fractional score } \\
\partial x_{i} & =\text { change in parameter " } x_{i} \text { " examined } \\
n & =\text { number of uncertainties examined. }
\end{aligned}
$$

A certainty level is given for each estimate for the eight resource variables, and uncertainty is assumed to be distributed normally about the most likely figure. The number that is then used for ranking purposes is the most probable minimum score. This assumption reflects the economic reality that firms investing in a risky venture are often more concerned with the possibility of the worst case than they are about the maximum project payoff. 


\section{Cost Estimates}

In order to evaluate the economics of an individual site, a technique was required which would estimate the minimum heat sales per unit of land and minimum heat sales price in dollars per MBtu which would be necessary for the successful operation of a district heating system. A computer program, HEATPLAN, developed for the Washington State Energy Office (Allen, 1983; Allen, 1984) was modified to allow for the use of the program to evaluate the entire commercial and applicable adjacent industrial sectors of each city selected for study. The commercial sector, or central core with adjacent industry was selected for detailed analysis because these areas can be realistically expected to be the first area to be served by a geothermal district heating system.

Site visits, city maps, and aerial photos were used to estimate the acreage of the central core. The commercial heat load was calculated based upon population, degree heating days, and outside design temperature (Allen and Shreve, 1980). Industrial process heat loads were only included if the industry was-located in close proximity to the central core area and loads were based on actual consumption data, or process/consumption estimates.

Capital costs include those generated by HEATPLAN, plus estimates of costs expected to be associated with exploration and resource development.

Ranking

The above methodology was applied to each of the 145 sites selected for detailed analysis and the sites were ranked based upon the integration of the results of the developability and economic analyses. The developability ranking is rendered in terms of the normalized minimum score received by the resource sites; that is a score between 0 and 1 indicates the relative favorability for the development of a site. A high score indicates a very developable site, a low score indicates a less developable one. Sites are ordinated by their developability scores to establish a ranking hierarchy. Following the specific site ranking, the scores are subjected to statistical analysis. Sites are then classified into three general groups with a more robust interpretation. All sites are then assigned into a normal distribution curve. Based on the standard deviation of the distribution, all sites are categorized into one of three groups. These are: sites with good development potential, those with average potential, and the others with poor potential.
Based on the mean value of the standard deviation, the sites were classified into these groups. Sites within one standard deviation of the mean were considered to be average sites. Those with a better score than one standard deviation from the mean were considered sites with good development potential. Those with scores less than one standard deviation from the mean were considered to have poor development potential. Table 10 shows the ranking group assigned for the direct use resources.

TABLE 10

Ranking Groups for Direct Utilization Sites

\begin{tabular}{lll} 
GROUP & \multicolumn{1}{l}{ SCORE RANGE } & NO. \\
Good & $.600-784$ & 17 \\
Average & $.480-.599$ & 113 \\
Poor & $.479-.410$ & 20
\end{tabular}

The second part of the ranking procedure adds the economic evaluation of the sites to the development potential assessment shown above. This allows a three by three matrix to approximate geothermal development feasibility in the Pacific Northwest area (Figure 15). The most attractive resources will be those with both high development potential and low cost of conserved electrical energy. This two way method is advantageous since it can account for conventionally estimated engineering and economic factors as well as less tangible institutional and market influences.

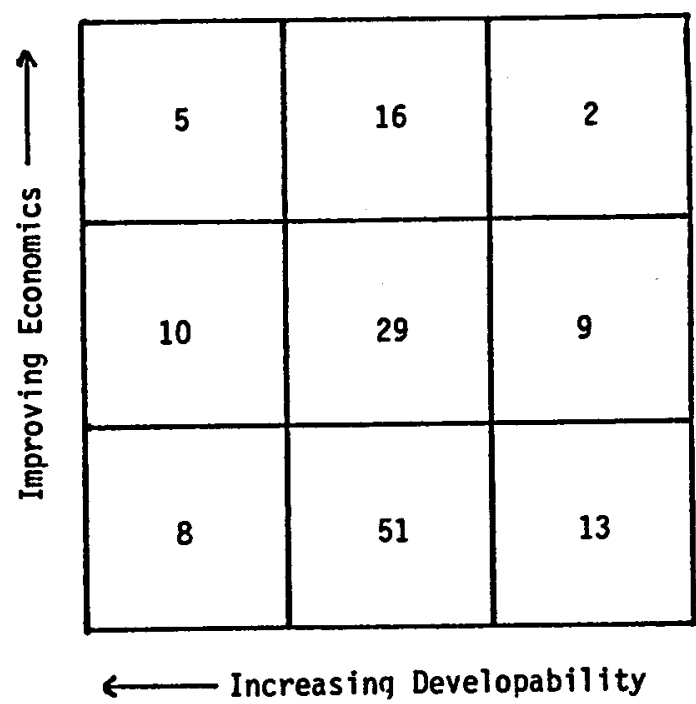

Most Developable/Most Economic

1. Boise, ID

2. Yakima, WA

3. Pocatello, ID

4. Pullman, WA

5. Klamath Falls, OR

FIGURE 15 - Direct Utilization Economic/Developability Matrix 
Delivered cost per million Btu was used as the proxy for economic rank of direct utilization geothermal sites. The cost per million Btu estimated by the HEATPLAN program ranged between $\$ 1.10$ and $\$ 2,732.80$. These results generally show that direct utilization economics are dominated first by load consideration and secondly by the resource quality.

In summary, 60 direct utilization sites, having a total minimum energy potential of $900+M W$ can be expected to provide substantial amounts of electrical offset at or below present conventional energy prices. 
LEGAL, INSTITUTIONAL, ENVIRONMENTAL ISSUES AND CONCERNS

\section{Introduction}

The ability to develop geothermal resources is often as dependent upon legal, institutional, and environmental factors as upon favorable geologic parameters. The economics of a project can also be seriously affected if legal and institutional problems cause serious delays in project implementation or environmental concerns require extensive mitigation measures to be taken. Because of this, a thorough review and analysis was undertaken in order to determine the effects which these factors could be expected to have upon the developability of each resource site as well as the cost of energy.

\section{Legal and Institutional}

The primary legal and institutional issues and concerns include: resource definition and characterization, ownership, resource access through leasing, groundwater law, and utility regulation.

Many of these issues are interrelated. Ownership questions, for example, are dependent upon how clearly and concisely legislators have defined and characterized geothermal resources. Differences in how federal and state governments have addressed these issues have often resulted in major conflicts of ownership and delays in leasing.

Legislation adopted by federal and state law makers to provide access to geothermal resources through leasing is often complicated, and in many instances, has proven to be more of an obstacle to development than an aid. Some of the most serious concerns include: 1) provisions for establishing competitive interest areas and the ways in which competitive areas are offered, 2) acreage limitations, 3) royalties charged on geothermal resources for direct utilization projects, and 4) provisions for the extension of the primary lease terms on federal leases.

Provisions of state and local groundwater law are also critical to geothermal development, and the ability to secure a water right can often be the difference between a successful project and no project.

A final issue of extreme importance is the role which state energy facility siting councils and/or utility commissions play in regulating geothermal projects.
These agencies have the power to determine when and where a project can be undertaken, whether or not easements will be granted, whether or not contracts can be entered into, and finally, the utility commission can exercise control over the rate of return which the developer can expect to earn.

The maze of legal and institutional requirements which exists in the region have caused serious delays in project implementation and can test the endurance and patience of most geothermal developers. Delays in obtaining necessary leases, licenses, and permits have often been as long as ten years, and such delays have been cited as the primary cause of the lack of geothermal assessment and development in the four state region.

The problems, however, have diminished, and although many of the barriers identified are presently being addressed, it is imperative that the states, BPA, and the responsible regulatory agencies work together to ensure that remaining barriers to geothermal exploration and development be removed in as timely a manner as possible.

\section{Environmental}

Although geothermal resources often are considered to be a relatively clean energy source which is environmentally benign, adverse environmental effects have occurred in various parts of the world due to geothermal exploration and development. The degree to which geothermal development affects the environment is, in most cases, proportional to the scale of such development. For example, the environmental impacts associated with geothermal direct utilization project often are minimal compared to those associated with electrical generation projects.

The main environmental factors to be considered during geothermal exploration and/or development include: the release of airborne effluents, water pollution, earth subsidence, induced seismicity, noise, water supply, solid waste, land use, vegetation and wildlife, and economic, social, and cultural factors.

Although air quality impacts which could be expected to result from a single geothermal facility would usually be 
minimal on a national or even on a regional basis, local effects may be significant because of site-specific factors. Hydrogen sulfide $\left(\mathrm{H}_{2} \mathrm{~S}\right)$ is usually considered to be the most troublesome of the gases because of its objectionable odor. However, available mitigation measures have been extremely effective in reducing $\mathrm{H}_{2} \mathrm{~S}$ emission and recent evidence indicates that $\mathrm{H}_{2} \mathrm{~S}$ emission, where proper mitigation measures are employed, will not cause serious vegetation damage (Thompson, et al., 1982; Gonzales, 1984). Boron has, however, been found to be a cause of stress and serious damage to certain native trees and shrubs near geothermal power plants at The Geysers, and must be considered to be a major concern to future development (Brownell, 1981). Radon emission, on the other hand, have had no discernable effect on the general environment near existing power plants or in downwind communities. However, recent concerns over the health risk which may occur from radon exposure make adoption of stringent controls likely, and the development of control mechanisms will probably be required.

Water pollution can be effectively controlled through proper drilling and casing program during drilling and by proper injection of brine and condensate.

Proper injection practices can also minimize problems with induced seismicity, and although problems of land subsidence can be much more difficult to control, injection of spent geothermal fluids to maintain reservoir pressure is critical.

One of the most often overlooked but most critical environmental issues is water supply. Many geothermal developments are occurring in arid areas where both surface and groundwater supplies are of critical importance for agricultural production and where existing water supplies are often fully allocated. This can severely limit geothermal developments which require large volumes of water for cooling tower make-up, injection to maintain reservoir pressure, and/or fluids for hot dry rock systems.

Cultural issues are also often underestimated or totally overlooked by geothermal developers. The existence of archaeological and/or historic sites may result in costly time delays or may even stop or severely limit geothermal development. Areas of high geothermal potential may also be places of high religious significance to various Indian groups and are protected through provisions of the American Indian Religious Freedom Act (Public Law No. 95-341) (United States Forest Service, 1981). The free use of such sites is guaranteed to the Indians by statutes and only through closely working with the Indians can conflict be avoided or minimized.

Geothermal development, as with any major development, can pose serious threats to the environment. The geothermal Industry has, however, benefited from the fact that most geothermal development postdates the passage of the National Environmental Protection Act. Because of this, regulatory agencies as well as geothermal developers have been forced to adopt policies and procedures which ensure a high level of environmental protection. Whether a need exists for ever greater protection is yet unknown, but if greater protection is deemed to be necessary, regulatory agencies and the geothermal industry have established a sound framework upon which to build. 


\section{SUMMARY AND RECOMMENDATIONS}

Commercial geothermal utilization in the Pacific Northwest region began nearly 100 years ago and despite this early start and the effort of the United States Department of Energy (USDOE) and the United States Geological Survey (USGS), geothermal development has been extremely slow due to a lack of basic information about the quality and extent of exploitable geothermal resources.

In 1983 this lack of information resulted in the Bonneville Power Administration requesting that the Washington State Energy Office coordinate a regional geothermal assessment program. The objective of the program was to consolidate and evaluate all avallable geologic, environmental, and legal and institutional information and to apply a uniform methodology to the evaluation and ranking of all sites in the region so that credible forecasts could be made of the geothermal energy which could be available in the region for electrical generation or electrical load offset.

To best accomplish the above, ' state agencies participating in the study were assigned the lead on tasks for which they possessed the greatest level of expertise.

The Four-State Assessment Team thus established began its work by identifying a total of 1,265 potential resource sites. The 1,265 sites were screened to ellminate those with little or no chance of providing either electrical generation and/or electrical offset. Two hundred and forty-five of the original 1,265 sites were determined to warrant further study.

Once the 245 sites had been selected, detalled information was collected and fully referenced for each site. This information has been entered into a computerized data base. This data base is stored on an IBM P.C. compatible microcomputer system using the R:Base 4000 (TM Microrim, Inc.) relational data base management system. This information formed the basis for all subsequent analyses including the determination of resource potential, developability, cost, and finally the ranking of all sites capable of generating electricity or offsetting electrical demand.
In compiling the data, it quickly became clear to the Team that very little detailed assessment data were avallable for most sites in the region. This lack of data makes precise determinations of resource potential almost impossible; however, the methodology developed by the USGS allowed the Team to make reasonable estimates of the magnitude of the resource potential. These estimates clearly indicate that the regional geothermal potential could provide several thousand megawatts of energy over a minimum of 30 years.

The ability to develop significant amounts of the identified potential is, however, often as dependent upon legal, institutional, and environmental factors as upon favorable geological parameters. Due to this, a thorough review and analysis of the legal and institutional framework was undertaken. The Team also made a thorough analysis of environmental laws and potential impacts that geothermal exploration/development can be expected to have on the environment.

The results of the legal and institutional analysis indicate that several problem areas need to be addressed. These include: ownership;

- Resource access;

- Groundwater law;

- Utility regulations; and

- Provisions for extension of the primary lease terms on federally administered lands.

The environmental analysis indicates that potentially most serious concerns are:

- Airborne effluents such as boron and radon;

- Land subsidence;

- Water supply; and

- Protection of cultural sites.

Once all available data were collected, a methodology was developed which would allow for the incorporation of the data into a site-specific ranking procedure which would be equally sensitive to resource characteristics as 
to the legal, institutional, and environmental factors which determines developability. It was thus determined that sites would be ranked on the basis of developability and cost.

The developability index is based on a weighted variable evaluation of resource favorability. Costs are determined by engineering and economic data developed for the Assessment Team by Bechtel National, Inc., and the Oregon Institute of Technology.

On the basis of the developability index, 78 high temperature sites and 120 direct utilization sites were ranked as having "good" or "average" potential for. development.

On the basis of cost, at least 29 of the high temperature sites appear to be technically capable of supporting a minimum total of 1,000 MW of electrical generation which could be competitive with the busbar cost of conventional thermal generating technologies. Another 60 direct utilization sites have an energy potential of 900+ $M W$ and can be expected to provide substantial amounts of electrical offset at or below present conventional energy prices.

Despite the finding of this study which indicate that substantial amounts of electrical generation or offset could be provided when needed through the exploitation of the region's geothermal potential, we are unable to say that this will be the case. Legal and institutional problems (presently compounded by the energy surplus) continue to impede exploration and development. Environmental concerns often create costly delays. And, finally, a lack of basic information about the quality and extent of geothermal resources continues to discourage regional energy planners from committing to geothermal development or including geothermal energy in long range energy forecasts.
Several actions could, however, be initiated to ensure that a significant portion of the geothermal potential that has been identified would be made available when needed. These include:

- A thorough evaluation of marketing opportunities and related factors should be undertaken as a way to encourage accelerated industry activity in exploration in the region.

- A detailed analysis of geothermal resource characterization and demonstration alternatives should be conducted to provide the region with the most economical assurance of geothermal being available when required.

- A detailed review and analysis of economic sensitivity of development/ownership scenarios should be initiated.

- The regional data base, established under the FourState Program, should be maintained and regularly updated to provide regional energy planners with the best possible information upon which to base future policy or acquisition decisions.

- Ongoing developments in conversion technology which are taking place in Nevada, California, and Utah should be carefully monitored so that the most efficient technologies can be applied to future regional geothermal development.

- Priority should be given to removing federal, state, and local legal and institutional barriers to geothermal leasing, exploration, and utilization.

- Baseline environmental data should be compiled for the most promising geothermal sites. These sites should represent a cross section of environments where extensive geothermal energy developments can be expected to occur so as to provide the keys to environmentally acceptable development. 


\section{REFERENCES}

Allen, E., and Shreve, J., eds., 1980, Preliminary inventory of western U.S. cities with proximate hydrothermal potential: Vol. 1, U.S.DOE Contract No. FGOG-79ET-27256.

Allen, Eliot M., 1983, HEATPLAN Version 1.0, account of work, Eliot Allen and Associates, Inc., for the Washington State Energy Office, Olympia, WA.

Allen, Eliot M., 1984, HEATPLAN Version 2.0 user manual, account of work, Eliot Allen and Associates, Inc. for the Washington State Energy Office, Olympia, WA.

Bechtel National Inc., February 1985, Cost relationships for geothermal power plants and wellfield surface facilities: Contract No. C50080 with the Oregon Department of Energy, Salem, OR.

BPA, 1984, Resource supply curves: DOE/BPA-250, Resource Supply and Evaluation Branch, Bonneville Power Administration, Portland, OR.

Brownell, James A., 1981, Cumulative biological impacts of The Geysers geothermal development: Staff report, California Energy Commission, 149 p.

Edmiston, R.C., 1982, A review and analysis of geothermal exploratory drilling results in the Northern basin and Range geologic province of the U.S.A. from 1974 through 1981: Geothermal Resources Council, Transactions, Vol. 6.

Geyer, John, December 1984, Personal Communication.
Gonzales, Gilbert J., 1984, The potential effects of hydrogen sulfide gas from geothermal energy conversion on two plant species native to northern New Mexico: Ph.D. Thesis, New Mexico State University, Los Alamos National Laboratory LA9984-T, 117 P.

Larkin, B., et al., 1984, Regulatory and commercial aspects of geothermal energy development: Acres Consulting Service Ltd., Nevin Sadlier-Brown Goodbrand, Ltd., Vancouver, BC, Canada, 295 p.

McClain, David W., 1980, A site evaluation model for geothermal resource development in southwest Idaho, Moscow, ID: University of Idaho, M.S. Thesis, 146 p.

Thompson, C.R.; Kats, G.; and Dawson, P.J., 1982, Effects of $\mathrm{H}_{2} \mathrm{~S}$ on crop and forest plants: Geothermal Resources Council, Transactions, Vol. 6, pp. 521-524.

U.S. Forest Service, 1981, Inventory of native American religious use, practices, localities and resource: Study Area on the Mt. Baker-Snoqualmie National Forest, Washington State, pp. 1-50.

Wright, B., 1985, Transmission Line Estimating Data Memorandum, February 11, Bonneville Power Administration. 
